Prof. A. G. Pugsley, O.R.E.

Dr. A. G. PUGSLey has been appointed to the chair of civil engineering in the University of Bristol formerly held by Prof. J. F. Baker, who was appointed in 1943 to succeed Prof. C. E. Inglis at Cambridge. Prof. Pugsley was educated at Rutlish School and Battersea Polytechnic, and graduated with first-class honours in engineering in the University of London in 1923. After serving as a student-apprentice in civil engineering at the Royal Arsenal, Woolwich, he was appointed a junior technical officer for design and research work at the Royal Aircraft Establishment Works, Cardington. In 1931 he transferred to the Royal Aircraft Establishment as a scientific and technical officer, where he is now the head of the structural and mechanical engineering department. In 1938 he was awarded the degree of D.Sc. of the University of London. He is a member of several sub-committees of the Aeronautical Research Committee and of the Ministry of Production. Dr. Pugsley has made notable contributions to engineering science, particularly in connexion with the structural design of aircraft and airworthiness, and the aero-elastic problems involved.

\section{British Non-Ferrous Metals Research Association:} Mr. G. L. Bailey

The British Non-Ferrous Metals Research Association has appointed Mr. G. L. Bailey as director to succeed Dr. H. Moore who has retired (see Nature, October 14, p. 482). Mr. Bailey graduated in metallurgy at the University of Birmingham, where he was awarded the degree of M.Sc. in 1922 after completing two years research work. During 1922-30 he was on the staff of the Research Department, Woolwich, where he carried out research on a variety of problems in non-ferrous metallurgy. During this period his most notable work was on the casting of $70 / 30$ brass ingots for subsequent rolling, the results of which were published in association with Dr. R. Genders by the British Non-Ferrous Metals Research Association in a monograph "The Casting of Brass Ingots".

In $1930 \mathrm{Mr}$. Bailey resigned from the Research Department at Woolwich to accept the appointment of development officer of the British Non-Ferrous Metals Research Association. In this post he was responsible for fostering the application of the results of the Association's researches in industry. He played, however, a wider part in the Association's organization and in January 1942 became deputy director. Mr. Bailey is a vice-president of the Institute of Metals and chairman of the London Local Section of that body.

\section{Lister Memorial Lecture of the Society of Chemical Industry}

ThE first Lister Memorial Lecture of the Society of Chemical Industry will be delivered by Sir Alexander Fleming in the Anatomy Lecture Theatre, University of Edinburgh, on November 9 at 5.30 p.m. The subject of the address will be "Antiseptics". Under the auspices of the Society of Chemical Industry, endowed memorial lectures have recently been founded in different parts of Great Britain to perpetuate the memory of scientific men and industrialists whose work has assisted in building up "the chemical industry. The name of the late Lord Lister has been chosen for commemoration in the Edinburgh and East of Scotland Section of the Society on account of his connexion with Edinburgh and because of the stimulating effect his revolutionary medical methods had on the growth of the fine chemical industry in Great Britain. The endowment has been the gift of two Edinburgh pharmaceutical chemical manufacturers, Messrs. J. F. Macfarlan and Co. and Messrs. T. and H. Smith, Ltd. The lecture will be delivered every four or five years in Edinburgh, Aberdeen or St. Andrews.

\section{Research on Tsetse Fly and Disease}

The Secretary of State for the Colonies has appointed a committee to consider and advise on the co-ordination of action, including research, directed against human and animal trypanosomiasis, and, in particular, against the tsetse fly as the chief vector. The committee, on which the Dominions Office and the Sudan Government are represented, will report from time to time to the Secretary of State for the Colonies, and on all matters affecting research its recommendations will be referred to the Colonial Research Committee for comment and advice before submission to him.

The committee is composed as follows: Mr. G. H. Creasy (chairman), Colonial Offce; Sir Robert Archibald, representative of the Sudan Government ; Prof. P. A. Buxton, London School of Hygiene and Tropical Medicine; Dr. H. Lyndhurst Duke, lately director of the Human Trypanosomiasis Institute in Uganda, and chairman of the League of Nations Sleeping Sickness Committee; Mr. S. A. Goulborn, Dominions Office ; Prof. I. M. Heilbron, Imperial College of Science and Technology ; Dr. E. M. Lourie, Liverpool School of Tropical Medicine; Sir Guy Marshall ; Dr. S. A. Neave, director of the Imperial Institute of Entomology; Mr. G. F. Seel, Colonial Oifice; Dr. A. G. H. Smart, medical adviser to the Secretary of State for the Colonies; Mr. John Smith, adviser on animal health to the Secretary of State for the Colonies; Dr. H. A. Tempany, agricultural adviser to the Secretary of State for the Colonies; and Mr. C. W. F. Footman (secretary), Colonial Office.

\section{Cinemicrography}

Two complementary papers dealing with cinemicrography were given at a meeting of the Association for Scientific Photography on October 14. Mr. H. Emmett described the apparatus used in one of the I.C.I. research laboratories, consisting of a petrological microscope, above which is supported the cine camera without its lens, while the microscope is also used without the usual eyepiece, but with a viewing attachment to enable the image to be kept under observation while being filmed. Focus on the film is ensured by inserting a piece of ground glass in the gate and balancing this image with the one seen in the viewing eyepiece; careful centring of the light is obviously of first importance. A $9.5 \mathrm{~mm}$ camera was used connected through a belt drive to an electrically controlled gramophone motor which enables exposures to be taken at known intervals. Mr. Emmett showed films illustrating crystal growth, such as the change in crystalline form induced by the presence of impurities, the allotropic change in acicular crystals of ammonium nitrate which can take place on lowering the temperature, and the concentration gradient around a crystal during growth.

The second paper, by Mr. R. MeV. Weston, entitled "Cinemicrography in Biological Research" dealt with similar problems but described a more elaborate 